\title{
THE PRAGMATICS OF CHAOS: PARSING BOLSONARO'S UNDEMOCRATIC LANGUAGE
}

\author{
A PRAGMÁTICA DO CAOS: \\ ANALISANDO A LINGUAGEM \\ ANTIDEMOCRÁTICA DE BOLSONARO
}

\author{
Daniel N. Silva ${ }^{*}{ }^{* *}$
}

\begin{abstract}
This paper unpacks different layers of Jair Bolsonaro's pragmatics of chaos - the name I give to a reflexive, ordered and laminated method of producing a permanent sentiment of agitation, murk, and discontent in political audiences while a conservative and free market agenda is radicalized in Brazil. The communicative layers are: history, exemplified by Bolsonaro's early career in the military: from his union-like activity, to his imprisonment and to evidences of a terrorist plot; persona, indexed by the jocular, non-serious performances that made him famous as a federal representative and that have been mediatized in his executive action as president; text and talk, characterized by a general texture of incendiary framing, smoke screens, backtracking, and avoidance of debate; audiences, seen from the perspective of the digital, pedagogic and performative populism that accrued from his campaign, almost entirely designed for being engendered on the non-public space of WhatsApp groups and in public, algorithmic social media platforms.
\end{abstract}

Keywords: digital populism; smoke screens; incendiary framing; backtracking; avoidance of debate.

\section{RESUMO}

Este artigo analisa diferentes camadas da pragmática do caos de Jair Bolsonaro - o nome que dou ao método reflexivo, ordenado e laminado de produzir um sentimento permanente de agitação, névoa e mal-estar em audiências políticas enquanto uma agenda conservadora e de livre mercado é radicalizada no Brasil. Os níveis comunicativos são: história, exemplificada pela carreira pregressa de Bolsonaro nas forças armadas: de sua atividade assemelhada a um líder sindical, à sua prisão e evidências de um plano terrorista; persona, indiciada pelas performances cômicas e não-sérias que o tornaram famoso como deputado federal e que foram midiatizadas em sua ação executiva como presidente; texto e fala, caracterizados

\footnotetext{
* Programa de Pós-Graduação em Linguística, Universidade Federal de Santa Catarina, UFSC, Florianópolis, SC, Brasil

** Programa Interdisciplinar de Pós-Graduação em Linguística Aplicada, Universidade Federal do Rio de Janeiro, UFRJ, Rio de Janeiro, RJ, Brasil.dnsfortal@gmail.com

Orcid: http://orcid.org/0000-0002-6098-5185
} 
por uma textura de enquadre incendiário, cortinas de fumaça, recuo, e evitação de debate; audiências, vistas da perspectiva do populismo digital, pedagógico e performativo que se consolidou em sua campanha, quase inteiramente desenhada para acontecer no espaço não-público de grupos de WhatsApp e em plataformas de mídias digitais, a um só tempo públicas e algorítmicas.

Palavras-chave: populismo digital; cortinas de fumaça; enquadre incendiário; recuo; evitação de debate.

\section{INTRODUCTION}

Scholars, political commentators and portions of the Brazilian society seem to agree that the success of Jair Bolsonaro's presidency is largely dependent on social chaos and institutional collapse. Brazilian philosopher Marcos Nobre (2019) has neatly summarized this point: "To undertake his authoritarian project, Bolsonaro needs to (...) keep the existing democratic institutions in the same state of collapse in which they have been since the mass protests of June 2013 - one of the decisive reasons underlying his election, by the way." Writing from Anthropology, Leticia Cesarino (this issue) argues that Bolsonaro's populist strategy, centered on the dissemination of his political message on WhatsApp groups and social media, has benefited from the state of disorder or entropy in the political system initiated in the large-scale protests of 2013, when millions of people took to the streets in Brazil to protest against a myriad causes, and especially against the quality of public services offered to the population.

Following the theory of populism put forth by Chantal Mouffe (2018) and Ernesto Laclau (2005), Cesarino found ethnographic evidence that the digital sphere has afforded Bolsonaro and his team the propitious means to present himself as an "outsider" during and after the protests, in addition to shortcutting the traditional channels of political debate (like the corporate media), rendering equivalent a plurality of demands for change in Brazil, and touting himself as the anti-establishment guy who is going to end the crisis created by the "enemy" the traditional parties, the corporate media, and the alleged legacy of corruption, "globalism" and moral degradation left behind by the Workers' Party in its four successive consecutive terms leading the executive. Yet unlike Laclau \& Mouffe's arguing that populism acquires its hegemony (i.e., some degree of stabilization) after a moment of crisis, Cesarino observes that populist tactics across the globe, especially in Brazil, have invested in a "chaotic, liminal-like environment, [marked by] political schismogenesis on and through social media" (this issue). While Laclau (2005) maintained that a "crisis of representation [...] is at the root of any 
populist, anti-institutional outburst" (p. 137) and that the free floating meanings of political signifiers in the moment of crisis will eventually be fixed as a "result of a hegemonic struggle" (p. 132), Cesarino (this issue) points that the Brazilian crisis of representation - paralleled in other democracies across the globe - has shown signs of a perennial limbo. In her words: "The sheer pervasiveness and potency of populist-style politics around the globe today suggest that liminality may be paradoxically becoming a more enduring condition" (this issue). Therefore, as is visible in Brazil today, chaos, crisis, and collapse are no longer a liminal space where populist leaders would drive their stakes to project some type of political stabilization through a populist hegemony; for Bolsonaro at least, chaos is instead the very "method", and his "telos", that which he seeks for.

In this article, I resort to some basic principles of linguistic theory in order to explain how Bolsonaro enacts his "pragmatics of chaos" in language. Inspired by Jacquemet's analysis of Trump's deceitful relation to truth (see JACQUEMET, in press), my parsing of Bolsonaro's linguistic pragmatics of chaos singles out three levels: Bolsonaro's jocular and incendiary locus of enunciation (section 3); the texture of chaos and denial in his text and talk (section 4); and his interested assembling of semiotic and digital resources that produce a toolkit for recursive and permanent agitation of audiences, both pro and against his politics (section 5). The remainder of this article is thus invested in mobilizing theoretical knowledge from applied, cultural and pragmatic strands of linguistics to depict these three layers of the current pragmatics of chaos in the Brazilian presidency. Yet I shall first look back to Bolsonaro's career in the Brazilian military (1973-1988) and legislative (1989-2018) to address the values of chaos, collapse and crisis in his early political life (section 2).

\section{A BOMB MADE WITH HIS OWN HANDS}

Even though Bolsonaro officially began his political career in 1988, when he was elected a city counselor in Rio de Janeiro in the first open elections after the end of the military regime, his public political performances became nationally visible sometime before, in 1986, in a place where one would never expect labor-unionlike political performances: the military. The description I offer below explains his cunning use of the print media while working in the military as a parachutist brigade captain. This description will help me unpack how Bolsonaro mobilized semiotic and linguistic resources to create a background of chaos, murk and fear while benefitting from this scenario to advance a political agenda. 
Although Bolsonaro brands himself as a retired army captain who will end crime and bring order to the country, he was far from being an exemplary officer during the 15 years he served in the military. In its recent history, Brazil was subjected to a dictatorship for 21 years, from the military coup of 1964 to the democratic reopening of 1985. During this time, Bolsonaro was a captain from the parachutist brigade, with records of insurrection. In 1986, Bolsonaro wrote an article for Veja, the major weekly magazine in Brazil, complaining that the paychecks in the Army were low (Figure 1). In the op-ed piece, he argued that, contrary to the newspaper accounts at the time, the departure of cadets from the armed forces had not been due to "homosexuality, drug use and a supposed lack of career talent" but to their low salaries (BOLSONARO, 1986). He extends the scope of the argument to other low-ranking personnel, whose patriotic duties were undervalued in the new republic. Bolsonaro expresses awareness that "trade union struggles are expressly forbidden in the army", and that his opinion piece could damage his very "devoted military career." In other words, even knowing that he could be arrested for publicizing his opinion about the military paychecks, he decided to act as a union leader. For him, "the imposition of a crisis and the lack of perspectives" for military officers was higher than the risk of being arrested. He ends up the article stressing that his dream of distinction (see BOURDIEU, 1984) was not being fulfilled by the salary, housing and other benefits offered by the State: in his words, "the basic necessities for a person with [his] cultural and social level" were not being met. 


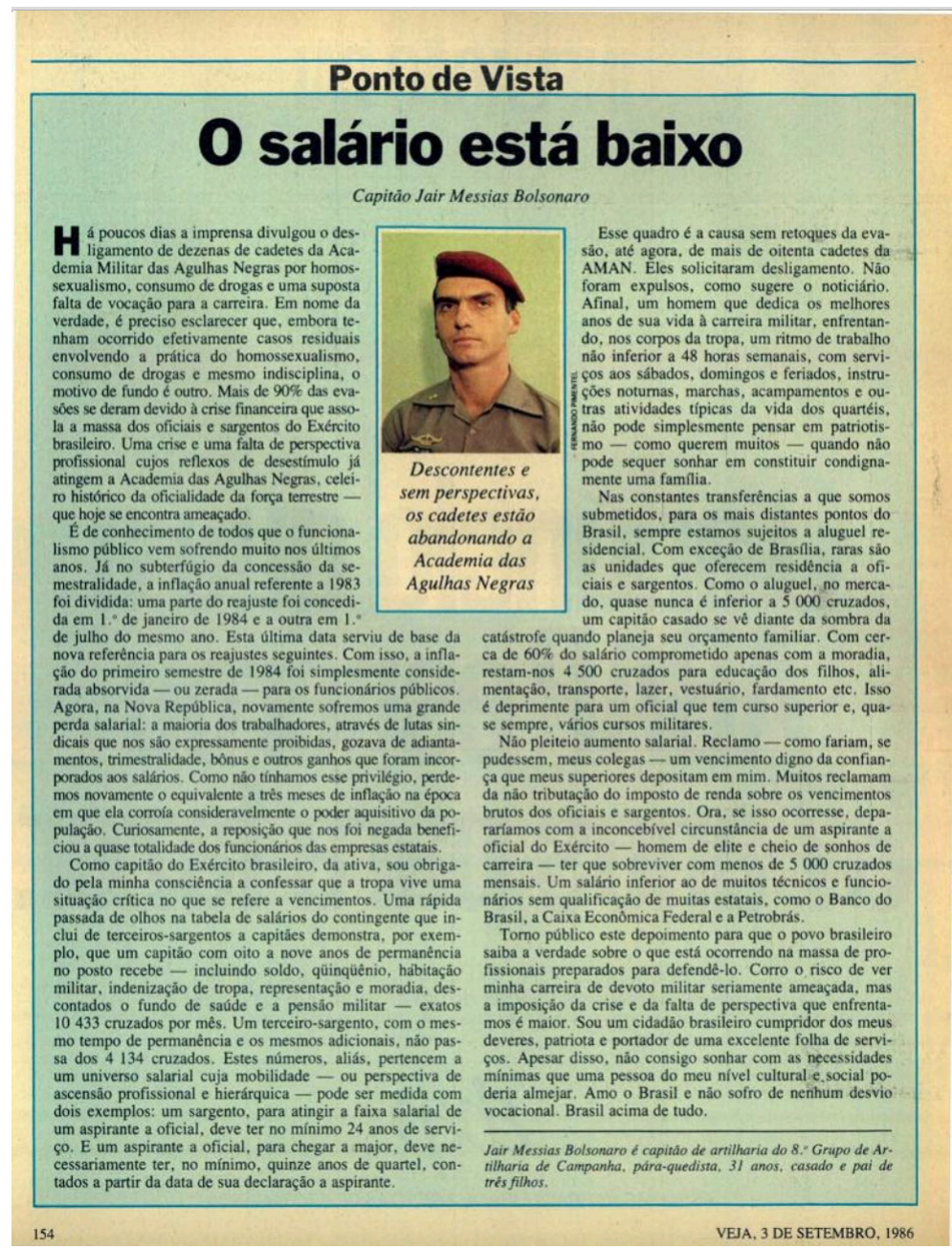

Figure 1. "The paycheck is low", op-ed article by Bolsonaro, Sept. 3, 1986

Under his picture: "Discouraged and without prospects, cadets are abandoning the Agulhas Negras Academy"

Copyright: Veja, Editora Abril.

His prediction was confirmed, and Bolsonaro was arrested shortly after Veja published his op-ed piece. The captain's writing was considered a transgression of the military discipline, and he stayed in prison for 15 days. His arrest triggered manifestations of solidarity by some of his peers, by a few of their wives, who carried their protest to the Army minister, and by a few readers of Veja and other 
news outlets. For the first time, Bolsonaro was capitalizing on the media to spread his political message, gather enthusiasts, and advance his agenda.

After his arrest, his plans of protesting against low wages continued (see Figure 2). A year later, he and other colleagues tried to harm the image of the Army minister, who they considered inept, by planning a bomb explosion at the Agulhas Negras Military Academy and in other units of the army. Cassia Maria, a journalist from Veja, had a private meeting with two captains - Bolsonaro and a man who presented himself as Xerife (Sheriff) - and Xerife's wife, Lígia. Cassia Maria learnt that they had been planning to craft a time bomb. Named Beco sem Saída, or Dead-End, the group's plan was to explode the bombs to demonstrate their dissatisfaction with salaries, and with the Army minister, Leonidas Pires Gonçalves. An account of their conversation was rendered into a section of the news article named "Ordem desunida", or Disunited Order, published on October 28, 1987 (Figure 2). In the section, Cassia Maria details the bombing plan, elaborates on Bolsonaro's outrageous comments (e.g. he calls his superiors "scoundrels" for imprisoning him), and cites his framing of the Army as a "national shame" and the minister as "a second Pinochet". (At this point, one may wonder why a group who intends to bomb an institution would disclose their plan to a journalist - perhaps their real plan was to rely on the media to instill fear and create an atmosphere of chaos for advancing a set of demands. The group also said that they didn't intend to harm any victims. "It is only a few fuses," Bolsonaro told Cassia Maria). 


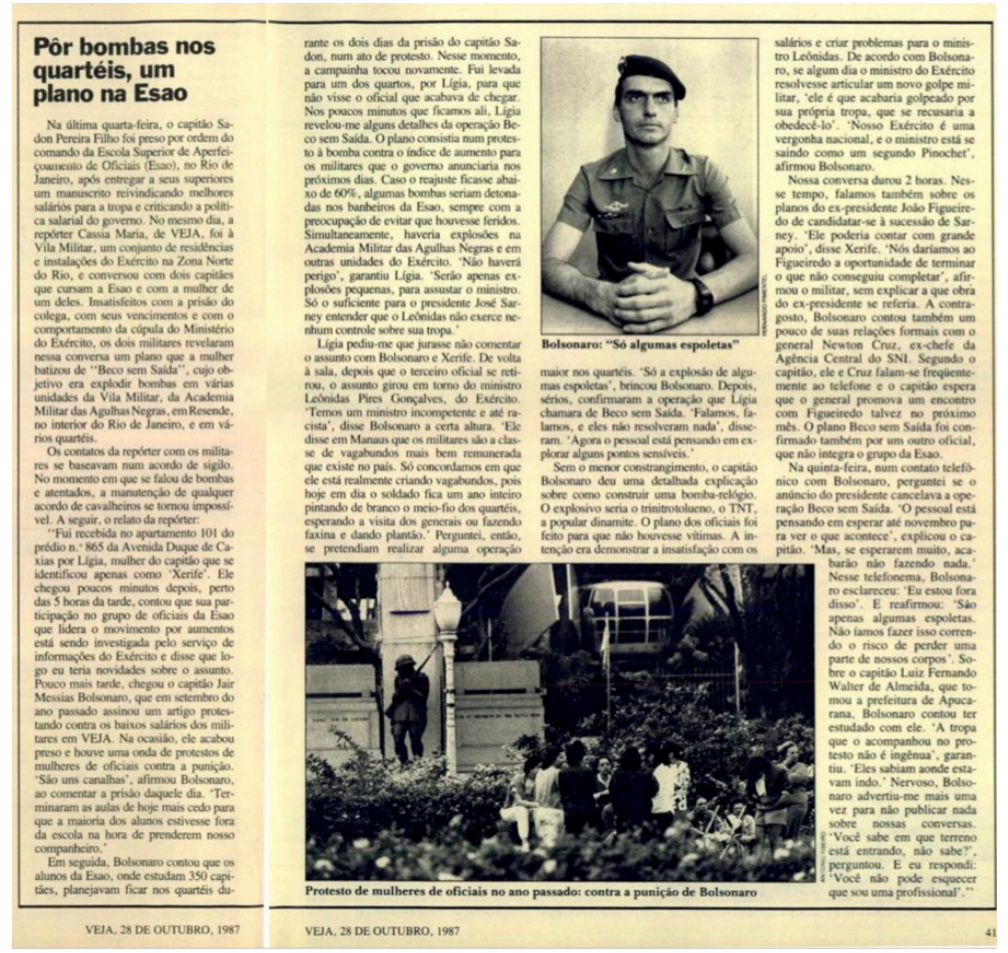

Figure 2. "Blowing up bombs in the barracks, a plan in the Army school." Veja, October 28, 1987.

Under Bolsonaro's picture: "It's only a few fuses". Under the lower picture: "Protest of officers' wives last year against Bolsonaro's imprisonment".

Copyright: Veja, Editora Abril.

In the following week, Veja published another news article about the DeadEnd operation (see Figure 3) This time, the magazine reproduced the drawings that Bolsonaro made with his own hands, detailing the bomb mechanism and some places to be hit (see Figure 3). Titled "With his own hand", the article is a response to minister Leonidas' argument that Veja would have faked the news story published in its previous edition. In the minister's words, "the two officers involved, I will repeat that, peremptorily and vehemently denied, in a document written with their own hands, that there is any truth in the information" published by Veja. In response, the magazine not only published Bolsonaro's sketches but also presented evidence that other witnesses had been with Cassia Maria in the multiple encounters she had with Bolsonaro and Xerife. The news magazine textually affirmed that Bolsonaro "lied" 
and that the minister should abide by the military law in the face of the evidences that Bolsonaro and his colleagues had a terrorist plan.

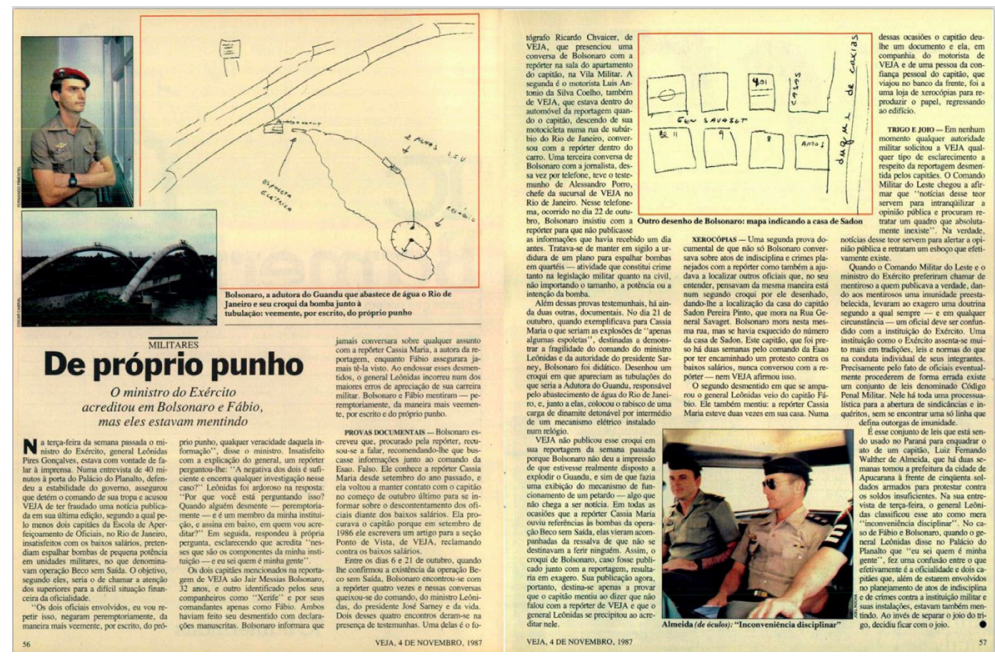

Figure 3. "With his own hand: The army minister believed in Bolsonaro and Fabio, but they were lying." Veja, November 4, 1987.

Copyright: Veja, Editora Abril.

Four months later, the minister acknowledged his mistake in believing Bolsonaro and Xerife (whose name was now known, Fabio Passos da Silva) before a proper forensic investigation had been carried out. After a preliminary criminal inquiry conducted by the army found that the sketches had been drawn by Bolsonaro, and that Veja had enough evidence that the conversations between Bolsonaro, Fabio, Lígia and Cassia Maria had really happened, Leonidas stated that the two officers should be ousted. He would then refer the case to the Military Supreme Court.

During his trial, Bolsonaro denied talking to the journalist, and didn't acknowledge having produced the drawings. Veja also reports that, during the trial, in "a moment of indisputable bad faith or delirium, Bolsonaro's lawyer told the ministers that Cássia Maria, who currently works for Jornal do Brasil, had been fired from Veja for lacking professional confidence." The magazine rebutted this claim by remarking that Cassia Maria had always been a "qualified journalist", and that the allegations that she had lied were false. Yet by nine votes to four, the military supreme court ministers decided that the forensic analysis didn't provide any conclusive evidence. Even though the Federal Police's forensic study pointed that 
the sketches were consistent with Bolsonaro's handwriting, a military commission found that "Bolsonaro's notes did not allow calligraphic comparisons, as he had used capital letters." In a clear pro-military action, Bolsonaro was found not guilty.

The trial took place in 1988, the same year that a commission of legislators of Brazil wrote the Constituição Cidadã, or Brazil's current Citizens Constitution. Along with other Latin American countries that experienced the trauma of military regimes, Brazil had produced a constitution that promised individual freedoms and social justice. At the same time that the Constituição Cidadã was being approved, Bolsonaro's verdict actually implied a hidden agreement. Carvalho (2019, p. 8) found documental evidence that the deal between the supreme judges and his defense was "an agreed game to preserve the captain - the spirit of the military force - in other words, as long as he hastened his departure from the army". After having been exposed in the media for two years, Bolsonaro decided to run for the city council in Rio de Janeiro. His decision of competing for a post in the city council was reported by Veja in July of 1988, a month after his trial:

Captain Jair Bolsonaro, who was recently acquitted of the accusation of planning to set off bombs in the restrooms of the School for the Improvement of Officers (Esao) in Rio de Janeiro, in protest against the low salaries of the military, has admitted since last week a possible candidacy for council member in the November elections. "I want to serve my country, and turning to politics is one of the alternatives," Bolsonaro said (Veja, July 20, 1988).

Thanks to his mediatic and union-like activity, Bolsonaro was elected council member of Rio de Janeiro in 1989, in the first open elections of the transition into democracy. As I said before, I bring this vignette about the beginning of Bolsonaro's political career to start unpacking some important patterns of his early communicative style ${ }^{1}$. First, the disclosing of the bomb plan to a journalist of Brazil's main weekly magazine meant that Bolsonaro was invested in reaching a wide audience by creating an atmosphere of fear and chaos. Second, as the plan was slowly being published by Veja, Bolsonaro traded on uncertainty by denying that he ever talked to Cassia Maria; that the drawings were not his; that Veja had fired Cassia Maria for her lack of professional credibility. As the pragmatic literature has vastly documented, even if an utterance is not true, it still produces epistemic effects (see JACQUEMET, in press; VARIS, this issue). So even by denying his participation in the plan, the very publicization of the potential bombing spread the word about

\footnotetext{
1. As I argued elsewhere (SILVA, 2019a, 2019b), due to his embedding of some features of this style into the algorithmic (MALY, 2018) and digital (CESARINO, 2019) affordances of social media Bolsonaro's speech acting has, since 2013, been a major authoritative and nodal point in the formation of a right-wing register that has emerged in Brazil in the past decade.
} 
discontent, insurgence, and rebellion in an institution centered on discipline and hierarchy. Third, Bolsonaro's bending the rules of military discipline - for instance, by writing an op-ed article complaining about the working conditions in the military - indexes an abiding mark of his political register, namely his benefitting from a normative regime while at the same time being outspoken against the same regime. After he moved from an undemocratic to a democratic institution, he amplified his scorn for the rules of democracy at the same time that he profited from the democratic game. For instance, in 1999, as a federal representative, Bolsonaro assessed the general democratic scenario of the time in the following terms: "You'll never change anything in this country through voting. Nothing. Absolutely nothing. Unfortunately, things will only change when a civil war kicks off and we do the work the [military] regime didn't. Killing some 30,000, starting with [President] Fernando Henrique Cardoso .... Killing them! If a couple of innocents die, that's OK" (THE GUARDIAN, 2018). In this comment, Bolsonaro was, ten years later, communicating social chaos, hate, and scorn for the very democracy that enabled him to be an elected representative.

As I hope to make clear in the next sections, this reliance on chaos, murk, and hatred became a regime of language in the current presidency of Brazil. Yet, as Blommaert points in his article to this special issue, the media and propaganda circuits that are available to politicians today are very different from the linear chain that I described above (see MALY, 2019; BLOMMAERT, this issue). In other words, if in the 1980s Bolsonaro relied on an enunciator-through-hegemonic-medium-topublic circuit to disseminate his message, today the algorithmic segmentations, and resulting micro-publics, afforded by communication technologies allowed his propaganda team to bypass Veja and other corporate outlets, thus consolidating a regime of language based on murk, confusion, and shock - all broken down to segmented audiences. As Kroskrity (2000) defines it, a regime of language is a poetic expression to envision the connection between language and politics - domains of human action that are often seen as separate. A regime of language is another form of thinking about language ideologies: rationalizations about language use and structure (SILVERSTEIN, 1979) that are the glue that ties forms of speaking to social processes (WOOLARD, 1998). Thus, Bolsonaro's incendiary and hateinducing utterances are not mere automatic instantiations of a disturbed mind, rather, they are ordered, systematic, and sometimes accompanied by linguistic rationalizations. Thomas Traumann (2019), for example, reports that when asked by a bank executive in the 2018 campaign why he "proudly displayed such theses as homophobia, racism and misogyny," Bolsonaro offered a suggestive linguistic- 
ideological comment in response: "I used to say that to appeal for attention. Nobody would look at me if I wasn't controversial. But outside of the TV I'm another person." While his private persona does not concern us here, let's now move to a linguistic analysis of his public persona.

\section{THE NON-SERIOUS PERSONA}

In their pioneering analysis of Donald Trump's gestures - an important semiotic resource that helped him ascend from a millionaire businessman and media celebrity to president -, Hall, Goldstein and Ingram (2016) point that the success of his candidacy in part resulted from its "value as comedic entertainment" (p. 71). In the mediatized sphere of politics nowadays, comedic performances "accrue visual capital" while shielding the performer from the seriousness of the propositional content of their utterances. Building on the work on carnivalization by Bakhtin (1984) and on framing by Goffman (1974), Hall, Goldstein and Ingram remind us that "[i]t is hard to critique a clown, we are too busy laughing" (p. 73). My point is that the affordances of comedic performance, play, and entertainment are key to understanding the persona that Bolsonaro projects to the public. His relationship with truth, his scorn for the traditional corporate news media, his fabricated populist style as "an average man from the people" who jokes about everything are embedded in the jesting celebrity style that made him famous over the decades. Yet it is not any type of joking that coheres with Bolsonaro's persona. Over the years, his jocular performances have been meant to be outrageous. As the country was progressively moving towards a "standard" social-democratic political register - for instance, predecessors of Bolsonaro like Fernando Henrique Cardoso, Luiz Inacio Lula da Silva and Dilma Rousseff all embraced political correctness -, sectors of the Brazilian population grew uneasy with the alleged muzzle of politically correct language (see RAJAGOPALAN, 2000; MORATO; BENTES, 2017). Bolsonaro's performances have thus addressed those who were displeased with the growing standards of anti-discriminatory language.

For instance, in 2011, Bolsonaro participated in an episode of CQC, a humorous TV show about politics, in which he answered questions asked by Preta Gil, a daughter of Gilberto Gil, one of Brazil's leading singers and an Afro-Brazilian activist. Preta Gil asked how he would react if one of his children fell in love with a black woman. He replied: "I won't debate promiscuity with anyone [...]. My children were very well educated and did not live in an ambiance like, unfortunately, you did" (RD1, 2019). During most part of his career as a federal representative 
(1991-2018), his outrageous comic performances had been treated as "bizarre" for progressives, "funny" for conservatives, and "crimes" for the justice system, that criminalizes hate speech and racism ${ }^{2}$. However, the delegitimization of the political system, the corruption scandals involving the giant state oil company Petrobras, and the digitalization of social and political life made it possible for Bolsonaro to transform his comical value into political capital.

In fact, no one would have ever dared to imagine in 2011, when Bolsonaro joked about Preta Gil's being an Afro-Brazilian, that someone who is a self-declared racist, misogynist, homophobe, and democratic detractor could be a viable candidate for presidency. A broader scenario of political and economic instability offered the proper terrain for Bolsonaro team's digital and semiotic strategy (see CESARINO, 2020). As regards the layer of leader-persona of this strategy, Bolsonaro's notorious hateful speech and outrageous jokes were patched together with the aura of an authentic enunciator: a man from the people who speaks his mind against the establishment; a retired captain who would bring law and order back to a corrupt civil political system; a politician whose homophobic and racist jokes are nothing but sweet symbols of non-serious play with Brazil's slavery past. This last point was made by Regina Duarte, a soap opera actress, often celebrated as "namoradinha do Brasil", or Brazil's girlfriend, who joined Bolsonaro's government in 2020 as secretary of culture. In 2018, she justified her vote on Bolsonaro by comparing him to her father:

When I personally met Bolsonaro, I met a sweet guy, a man from the 1950s, like my father,
who makes homophobic jokes, but it's from the mouth off, a macho way that dates back to
Monteiro Lobato, who called Brazilians lazy and said that a black person's place is in the
kitchen. I could have voted for other candidates, like (Geraldo) Alckmin [from the center-
right PSDB] and (João) Amoêdo [from the recent libertarian Partido Novo], but at that
moment I realized unbelievable things, like the omissions of the PSDB. It all got very ugly.
How many mistakes, how many mistakes! That's when I noticed the scale of Brazil's adherence
to Bolsonaro, and I thought: I am this country, I am this country’s girlfriend. (METRO, 2018)

Like many supporters of Bolsonaro, Regina Duarte offers above an ideological justification for the racist and homophobic register of her candidate: for her, his charisma mirrors the speech of average Brazilians like her father (who was also from the Army). Duarte also couches her rationalization about Bolsonaro's

2. Bolsonaro was convicted of crime of racism for his reply to Preta Gil. The penalty, however, was not detention, but financial compensation to the Ministry of Justice's defense fund in the amount of R \$ 150,000.00, or roughly US\$75,000.00 in 2011 (see RD1, 2019)

3. Monteiro Lobato is a Brazilian fiction writer who was born in the $19^{\text {th }}$ century, shortly after slavery was abolished. Currently, his works have been part of heated debates about whether his portrayal of racial relations was racist or not. 
enunciative persona in the well-known denial of rampant racism and racial inequality in Brazil (SALES JR., 2006; PINTO, 2015; REICHMANN, 1996), something that fractalizes itself into a common everyday dismissal of widespread homophobia, sexism, and class inequality. As I detailed in a paper about how team Bolsonaro participated in the enregisterment of a novel right-wing language in Brazil (see SILVA, 2019a), the novel image of Bolsonaro iconizing an alleged national charisma is a carefully fabricated populist strategy. We have seen in section 2 that, in his first appearance in the national media, Bolsonaro complained that his salary couldn't afford the aspirations of someone with his "cultural and social level" - he was therefore differentiating himself from "the people", especially in a country where a sizeable part of the population live in poverty. His campaign thus has built on the image of a simple man, something that iterates Lula's charismatic populist persona as a man who spoke, dressed and behaved like the people (SIGNORINI, 2014; COUTINHO; LOPES; SILVA, 2017). Figure 4 is an example of how Bolsonaro mediatizes his public persona as a man from the people: taken on February 14, 2019, when his government's reform of pensions was approved, the picture displays him wearing pajamas and flip flops, next to some of his ministers and allies. As regards his cannibalization of images from the left, like Lula's popular register, Cesarino points in this special issue and other publications (CESARINO 2019, 2020) that, very often, "signifiers in the Bolsonarist camp are constructed as inverted mirrors of those on "the left" (this issue). She reminds us that Bolsonaro's face logo in the presidential campaign is an iteration of Jim Fitzpatrick's world-famous portrait of Che Guevara (see Figures 5 and 6). Translating Cesarino's terms to linguistic theorizing, this cannibalization of the enemy's propositional content, register and semiotic style is coherent with the mechanics of populism (MOUFFE, 2018; LACLAU, 2005). The inverted mirror draws from a citational past - a collective memory - that is restructured as the camp of the people, now oriented to the right, fighting an "enemy." 


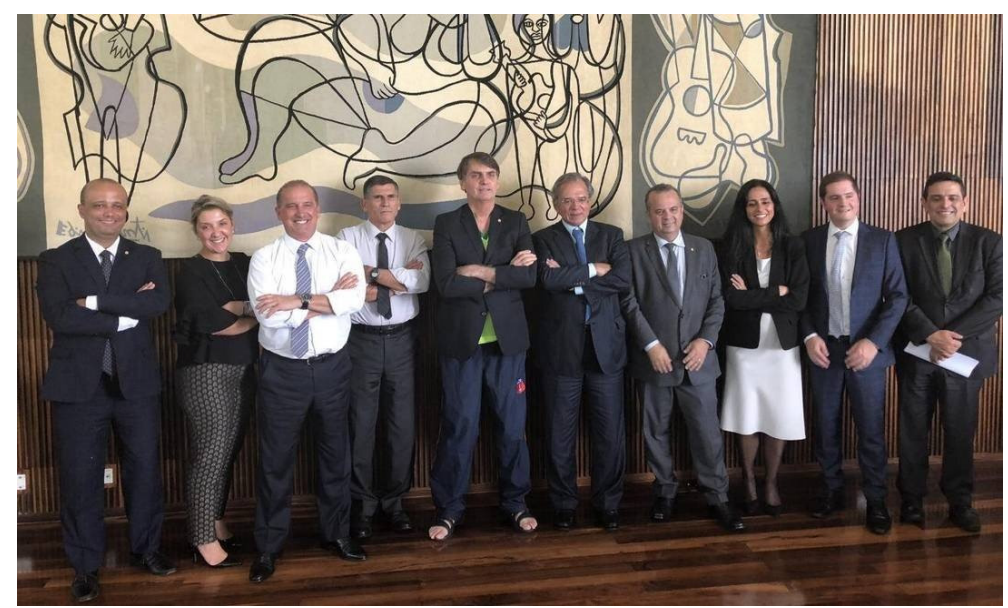

Figure 4. Bolsonaro wearing pajamas and flip flops, next to his ministers and advisors. February 14, 2019.

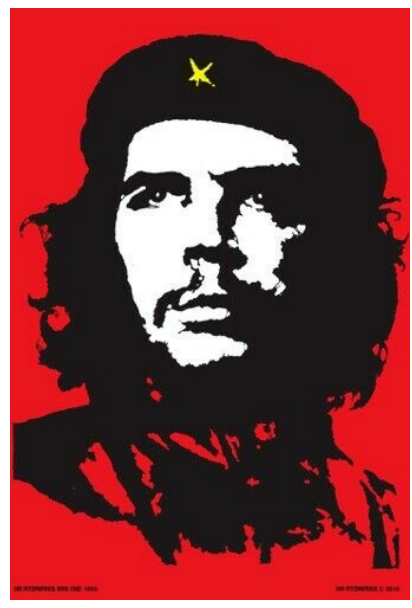

Figure 5. Jim Fitzpatrick's Che Guevara

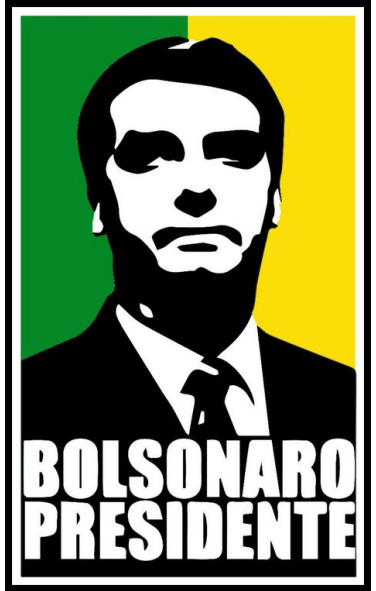

Figure 6. Bolsonaro's Presidential Campaign logo

This jocular, "popular" style is also pivotal for understanding Bolsonaro's relationship with truth. As I write this article, the entire world is being hit hard by the Covid-19 pandemics. Against the World Health Organization's (and his own Health Ministry's) concerns about the severity of the viral infection and guidelines of social isolation and distancing, Bolsonaro has urged Brazilians to go back to normal life by calling the disease a "gripezinha" and a "resfriadinho" (a minor flu and a minor cold). One of his derisive mediatic performances were publicized on 
Twitter by his son, Eduardo Bolsonaro, on March 26, 2020. On a post that reads "bom dia" (good morning), Eduardo Bolsonaro, who is a senator for the state of São Paulo, posted a video of his father ridiculing journalists in Brasilia. In the video, first, one sees a few supporters of Bolsonaro standing in the sheltered area of the exit of a building in Brazil's capital city Brasília. They shout "amen". The camera is displaying Bolsonaro in the foreground and the supporters in the background (Figure 7). Bolsonaro then asks the cameraman to turn the camera to the outside area of the building. It's raining. Under a tree and holding umbrellas are about a dozen reporters (Figure 8).

Bolsonaro then tells the camera, often gazing at the distant reporters: "Attention, Brazilian people, these journalists say that I am wrong and that you have to quarantine yourselves at home. Now I ask you reporters: What are you doing here?" (Figure 9). In the background, one hears the voices of the supporters: "bravo, Bolsonaro! Myth!" He adds: "You [journalists] are not so afraid of the corona virus? Go home." We can' t hear any answers from the reporters. They remain in the background, under the rain, humiliated. Meanwhile, some supporters shout, "Globo Lixo", or Trash TV Globo, in a ridiculing reference to Brazil's main TV channel. A woman wearing a yellow T-shirt with the Che-Guevara-like-logo "Bolsonaro President" says, "We're about twenty people, and we want to say we're praying, and we're with you" (Figure 10). He bids farewell to the group of supporters, who repeat: "We are with you".

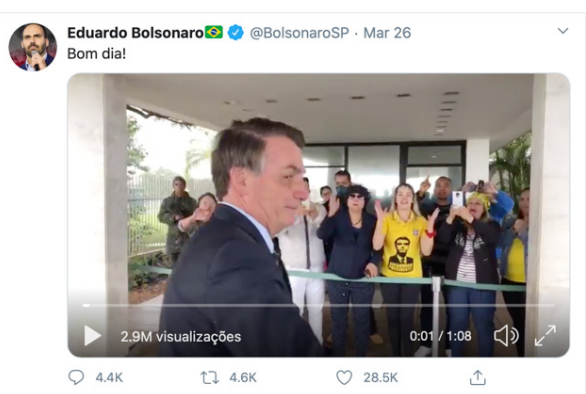

Figure 7

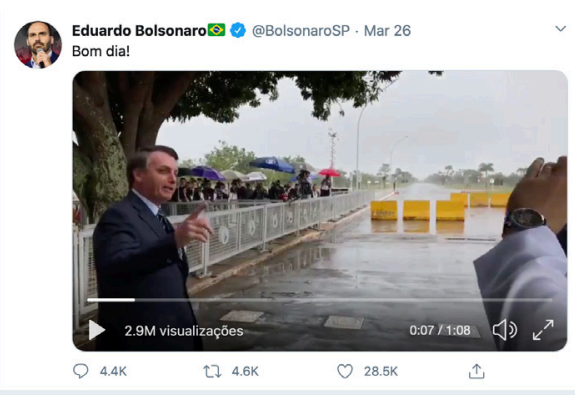

Figure 8 


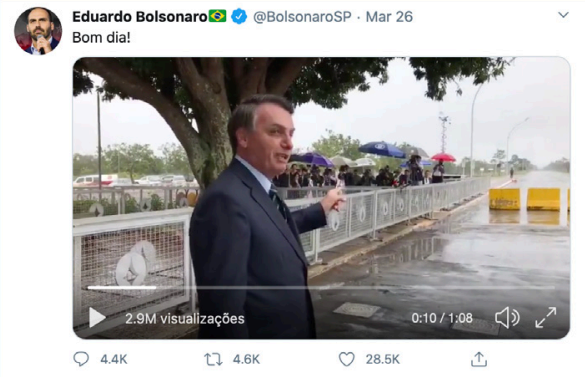

Figure 9

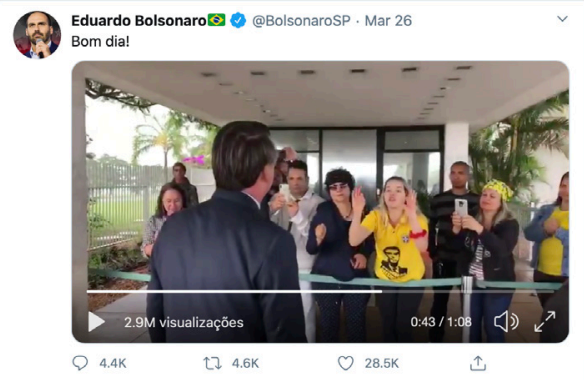

Figure 10

In his study of Donald Trump's disregard of scientific evidence, and of truth in general, Jacquemet (in press) revises the distinction between lying and what the literature has technically framed as 'bullshitting' (see FRANKFURT, 2005). Jacquemet points that while both the liar and the bullshitter want to evade factual accuracy, the first is concerned with hiding or misrepresenting truth, and the second has no concern whatsoever with what is true. Bullshitting is thus "spoken without any concern for the truth. It can be true or false, but the speaker does not really care $^{\prime \prime}$ (p. 108). Therefore, Bullshitting is less about factual accuracy - i.e. the truthfunction of a statement in logico-semantical parlance - than about the bullshitter's own "impression management": for Jacquemet (in press, p. 107) "what a bullshitter cares about is accomplishing positive impression management through speech. The bullshitter's goal is not to convince others of any supposed facts. It is, rather, to shape his listeners' beliefs and attitudes about himself" (Jacquemet's use of generic "he" is intentional, perhaps invoking the sexism embedded in bullshitting).

In the video, Bolsonaro indeed looks to be bullshitting about the covid pandemics. In his performance, he doesn't care whether the virus is contagious or not; whether social isolation is effective or not; whether his prevarication vis-à-vis the pandemics will cost him impeachment or not. What he cares about is pleasing his public and making them laugh through his ridiculing and humiliating of the enemy - Rede Globo, after all, has been observant of rules of social distancing, and has reported on the acknowledged science informing scientific and public health institutions. As studies on verbal art and performance have demonstrated (BAUMAN, 1984; BRIGGS, 1988), the center of gravity for Bolsonaro's political discourse is not what be says (or Searle's propositional content) but bow be says it (or Jakobson's poetics). In this jocular mediatized performance, society is divided in two camps: on one side, the "people", i.e. those who are religious ("we're praying for $\left.\mathrm{you}^{\prime \prime}\right)$, patriotic (at least three people are wearing the colors of the Brazilian 
flag), politically incorrect (they call him a myth when he scorns the journalists); on another side, the "system", i.e. journalists who turn out to represent the scientific, mediatic and political "establishment." In the center of this formal mechanism stands the figure of the leader, who, according to Laclau (2005) and Mouffe (2018), is necessary for the efficacy of this opposition. Building on Freud, Laclau (2005, p. 83) says that "the leader [is] a central condition for consolidating the social bond" in populism.

Yet, if my intuition about this general framework of chaos, collapse, and societal divide is correct, one may wonder about the precariousness of any bonds consolidated by Bolsonaro. I now move to the texture of his verbal performance.

\section{4. (TEAM) BOLSONARO'S TEXT AND TALK}

Eliane Brum (2018), a Brazilian political commentator, wrote in the Guardian that Bolsonaro's disinterest in truth "is less a post-truth phenomenon than a phenomenon of what [she] call[s] self-truth". For her, self-truth works in the same way that bullshitting does: "The content of what [Bolsonaro] says doesn't matter: what matters is the act of saying it. Aesthetics have replaced ethics." In her account, Bolsonaro has transformed truth in "an absolute and a personal choice. The individual has been taken to a radical extreme." Yet while I agree that Bolsonaro radicalizes his own views of reality and that the content of what he says matters less than its aesthetics or poetic form, I disagree with Brum that we would be handling here with matters of "personal choice". As Jacquemet (in press) and the anthropological tradition he follows (e.g. GUMPERZ, 1982; ROSALDO, 1982; BAUMAN; BRIGGS, 1990) remind us, focusing solely on the enunciator and their intentions - in the case of Trump's bullshitting for instance - "may produce a reification of the autonomous speaker at the expense of understanding the overall ecology of the bullshitting event" (p. 109). In Bolsonaro's case, the texture of his text and talk is hardly the product of his intentions alone; in many ways, Bolsonaro follows scripts, reads teleprompters, and talks according to tactics designed by his military and "hatred cabinet".

Gabinete do ódio, or Hatred Cabinet, is the informal name given to an office on the third floor of the Planalto Palace, the official workplace of the president. According to representative Joice Hasselman, a former Bolsonarista who broke with him, the Hatred Cabinet structures part of Bolsonaro's hate messages, spreads fake news on social media, and orchestrates semiotic "attacks" on adversaries. It is comprised of three main advisors - Tércio Arnaud Tomaz, José 
Matheus Sales Gomes, and Mateus Matos Diniz - friends with Carlos Bolsonaro, a council member in Rio de Janeiro, and also Bolsonaro's second and the most prominent digital strategist of his father. The cabinet members share with Carlos Bolsonaro and his father an admiration for Olavo de Carvalho, a flat earther and science skeptic who self-proclaims as philosopher. Other advisors, like Felipe Martins (who advises Bolsonaro in international themes) and Leo Índio (a cousin of Bolsonaro's sons), also participate in the Hatred Cabinet. It is believed that some of the radical performances of Bolsonaro are planned in this office, such as the July 2019 diplomatic incident between Brazil and France. Bolsonaro cancelled a meeting with French Foreign Minister Jean-Yves Le Drian, who received notice of the cancellation just one hour before; at the time the meeting was supposed to happen, Bolsonaro played a live streaming on social media to his "base" while cutting his hair in a salon (PARAGUASSU, 2019).

Even though the Hatred Cabinet is relatively well known in Brazil, the planning of Bolsonaro's digital strategy is hidden, and possibly extends beyond the Hatred Cabinet. In her discussion of Bolsonaro's digital populism, Cesarino (2019) writes: "Given the ubiquity and consistency of the [...] discursive patterns [in Bolsonaro's campaign], it is hard to believe that the construction of Bolsonaro's digital campaign did not involve some kind of 'science of populism'". As I read her work, evidence of this science of populism is indirect. Below, I want to elaborate briefly on some consistent patterns that are responsible for the pragmatics of chaos that I have been alluding to in this article. The patterns are: incendiary framing; smoke screens; backtracking; and avoidance of debate.

First, incendiary framing is both a metaphor to what I described in an article about Bolsonaro's role in the fires in the Amazon in 2019 (SILVA, 2019b) and a broader textual pattern of being outrageous, responding to critique with slurs, and inciting the communicability (or text and metapragmatic virality) of hate and fear. An example of this incendiary framework comes from Bolsonaro's activity before and during the fires in the Amazon in 2019 (see SILVA, 2019b). Criminal and journalistic evidence indicates that the higher intensity of the fires - in a month of August that had not been usually dry - was due to planned actions by pro-Bolsonaro land-grabbers and ranchers who gathered on WhatsApp groups to fell down trees and set them on fire as a form of "communication" with Bolsonaro. His supporters wanted to say through the medium of fire that they had heard the president's message about indigenous peoples being undesirable and holding too much land; about global warming being a globalist hoax; about monoculture and cattle ranching being economically better than preservation, and about environmental 
enforcement in the region being dismantled. To anticipate the next section, this response from the audiences of Bolsonaro points that they understood that disaster and chaos can also be a political method. In terms of Charles Briggs' $(2005,2011)$ theory of communicability - i.e., the easy, viral spread and the meta-messages of discourses -, the fire spread across different social spheres, inciting and forming audiences, positionalities, and modes of interpellation; the communicability of fire also suggested metapragmatic models, i.e. ways of reading and reflecting on this political message. The fires in the Amazon were consistent with Bolsonaro's incendiary attitudes prior to the incident: to the scientific community's dismay, he had ousted a renowned physicist, Ricardo Galvão, from the presidency of INPE, Brazil's spatial institute in charge of measuring deforestation, he had tried, unsuccessfully, to withdraw the country from the Paris agreement; he had rejected hosting the UN environmental summit in 2019. During the fires, he engaged in new diplomatic incidents with France, this time with President Macron, whose position pro-EU and social democracy is redefined in the Bolsonarist camp as globalism and imperialism. He also insulted Mr. Macron's wife, Brigitte, who is some twenty years older than her partner, by suggesting that she is old and ugly (EMBURY-DENNIS, 2019). Without presenting evidence, he also blamed indigenous peoples and NGOs for burning the forest to destroy his image. The recurrence of this incendiary way of framing disasters and even daily events - by inciting hatred and destruction, by insulting political adversaries, and by inflaming audiences - is recurrent, pervasive, and recursive, indicating that there is method in this mode of framing events.

Second, smoke screens result from (team) Bolsonaro's incendiary framing. My use of smoke screen refers to the textual-semiotic strategy of causing dispersive effects in the publics - by means of outrageous social media posts, absurd performances, offensive language or images, even pornography - that diverts attention away from accusations of corruption, meager economic results, and other negative news. Together with incendiary framing, smoke screens contribute to the general scenario of doubt, murk, and skepticism in Bolsonaro's populism. As the Oxford Dictionary defines, smoke screen is "a cloud of smoke created to conceal military operations". We must not lose sight of the fact that Bolsonaro's government is largely supported by and composed of military members; smoke screens were digitally enacted in the campaign and remain active in the current executive strategies, thus consistent with military attempts of producing dispersive effects. Journalists and progressive sectors of the public have argued that smoke screens produced by Bolsonaro and his team are effective in "controlling the agenda" of what gets to be discussed and what ought to be silenced or remain in the background. Leonardo Sakamoto (2020), 
a progressive journalist, has counted at least eight orchestrated smoke screens in the first fifteen months of Bolsonaro's presidency. For instance, on March 4, 2020, when the Federal Statistics and Geography Institute (IBGE) released the low result of economic growth for 2019 (1.1\%), Bolsonaro orchestrated a performance outside the Alvorada Palace in Brasilia. He hired a comedian dressed as president to give bananas to the journalists. When asked by reporters about the low GDP growth, he questioned back: "GDP? What is a GDP?" A second example is related to a corruption scandal involving Flavio Bolsonaro (his first son and a senator from Rio de Janeiro), and Flavio's advisor, Fabricio Queiroz. According to the public prosecutors, Flavio hired "ghost" workers for his cabinet, their paychecks would be partially reverted to Queiroz, who would collect it and give back to Flavio. Michelle Bolsonaro, the first lady, also had money deposited in her account by Queiroz; Jair Bolsonaro alleged that the money was actually the settlement of a debt, but he didn't present any proof of it. When asked about the accusations, he instilled a smoke screen by invoking the sexuality of a reporter. Bolsonaro said: "You have a terrible homosexual face, I don't accuse you of being homosexual, even though it's not a crime to be homosexual". Later, when another reporter asked about proof that the money Queiroz has deposited in Michelle Bolsonaro's account was really the payment of a debt, the president replied: "Ask your mother for the proof she gave to your father, okay?" A final example comes from the carnival of 2019. The first accusations about Flavio Bolsonaro's advisor, Fabricio Queiroz, were being filed in court. It was also becoming clear that Flavio Bolsonaro was connected to the Escritório do Crime, or Crime Bureau, a militia that is possibly involved in the murder of the councilwoman Marielle Franco in Rio de Janeiro. To disperse the negative news, Bolsonaro posted a pornographic video on his twitter. It is a video of two men practicing sex and performing a "golden shower" in carnival. As a "caption" to the video, he wrote: "This is what many street blocks in the Brazilian Carnival have turned into." Ranging from comic appearances, to homophobic slurs, and to explicit sexual content, these public performances of Bolsonaro are meant to shock audiences, while also diverting public attention away from sensitive issues.

Third, backtracking refers to the exploitation of the perlocucionary effects (AUSTIN, 1962) - or chained "reactions" - of the shock, ambiguity and potential chaos embedded in executive actions or official statements. Through backtracking, Bolsonaro and members of the executive power first announce controversial decisions - such as the potential transfer of the Brazilian embassy in Israel from Tel Aviv to Jerusalem. After gauging its acceptability, or the resulting chaos, Bolsonaro may backtrack by either deciding to change course, or by completely abandoning 
the controversial executive act. In his attempt to transfer the Brazilian embassy in Israel to Jerusalem - a simultaneous index of allegiance to Donald Trump and a form of pleasing his evangelical base -, Bolsonaro had to grapple with the immediate discontent expressed by strategic commercial partners like Egypt. $\mathrm{He}$ first backtracked by saying that he was actually thinking of deploying a diplomatic office, and finally fully backtracked by deciding not to do anything and leave the embassy where it has always been, Tel Aviv. Some supporters of Bolsonaro receive his backtracking as yet one of his popular attributes; like an ordinary man, he would have no problem admitting his mistakes and backtracking; it would also be a sign of his "openness to accept criticism" (FERRARI, 2018).

Fourth, avoidance of debate is both a reference to how Bolsonaro got elected and to a common tactic of his government. During the presidential campaign in 2018, Bolsonaro either performed very badly in the live debates with other candidates or failed to show up in scheduled debates. The fact that he was stabbed ahead of the first round of voting offered him the ideal conditions of running his campaign from home, without having to engage in debates with other candidates or with the media. In the presidency, Bolsonaro and his ministers usually leave press conferences or interviews when asked about uncomfortable topics. An interview with the Minister of Women, Family and Human Rights, Damares Alves, apparently explored the pattern of avoidance of debate to produce amplified attention. In November 2019, she had called a press conference at the Palácio do Planalto. She arrived at the location with a visibly upset face, did not greet the reporters, and remained silent for 30 seconds. She finished the interview by raising her hands and shaking them as if denying something, and left without saying a word (see Figure 11). Hours later, she posted a video on Twitter explaining that her earlier appearance was actually a staged performance to emulate how women behave when crushed by domestic violence. Yet regardless of her silent interview being either an avoidance of debate or a staged performance, Damares built on the general uncooperativeness of (team) Bolsonaro's regime of language. In his analysis of Trump's mediatized rhetoric, Jacquemet (in press) points that Trump's tweets and communicative action in general fails to meet Grice's (1975) Cooperative Principle, a rational model of conversation. In his classical model, Grice proposed that speakers aim to cooperate with one another - which does not mean agreeing with others but exploiting maxims of conversation. Following Kant, Grice systematizes these maxims as 'quality' (i.e. say that which is true), 'relevance' (i.e. say that which is pertinent to the conversation), 'quantity' (i.e. provide enough information), and manner (i.e. be clear and orderly in your conversational contribution). By flouting one or more of 
these maxims, Grice argues, speakers generate implicatures, or implicit meanings, that hearers may guess by following, as rational agents, the Cooperative Principle. For instance, a recommendation letter for a post of mathematics teacher that says that the candidate has good handwriting and is never late for meetings flouts at least the maxims of relevance and quantity, for good handwriting is not relevant for excellence in math teaching, and good knowledge of the discipline is amongst the items to be listed in the quantity of information of such a letter. In Grice's rational model, Damares flouts at least the maxim of quantity, for she is completely silent and does not provide minimal information for a conversational exchange. Yet, at the same time, she is not willing to cooperate at all: her interview is a non-interview; her communication is the breakdown of communication.

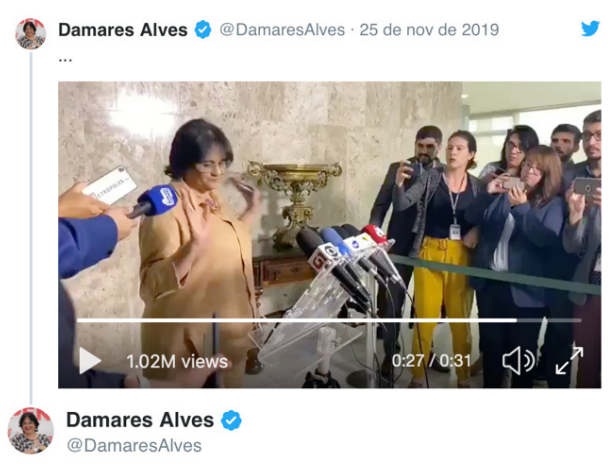

Ninguém entendeu meu silêncio, mas agora eu explico pra
vocês.

Denuncie a violência contra a mulher. Ligue 180.\#vctemvoz

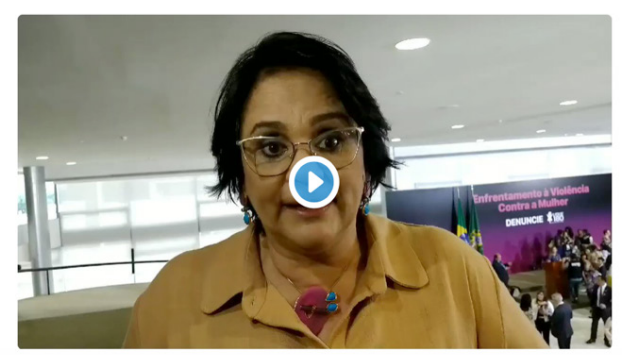

○ 22,4 mil 13:41 - 25 de nov de 2019 · Brasília, Brazil

Figure 11. Minister Damares Alves' silent interview, November, 25, 2019

"No one understood my silence, but now I explain it to you.

Report violence against women. Call 180." 
Like Damares and most of his advisors, Bolsonaro is uncooperative in his use of text, talk and image. More often than not, Bolsonaro does not provide evidence for his claims (maxim of quality), leaves interviews without providing minimal information (maxim of quantity), avoids confrontational questions by insulting or bringing off-topic comments (maxim of relevance), and is obscure, ambiguous and relativist (maxim of manner). The same assessment that Jacquemet (in press) makes of Trump's bullshitting applies to Bolsonaro's: "some of Trump's [bullshitting] seems bent on violating all of Grice's maxims [which indicates that] maxims [are] violated because the speaker is not following the Cooperative Principle" (p. 110). Therefore, the texture of Bolsonaro's text and talk is aimed at binding people through noncooperation - i.e. chaos, shock, confusion. Therefore, the social bond promoted by the Brazilian leader is a wounded, divisive one.

\section{AUDIENCES AND WOUNDED ATTACHMENTS}

In this final section, I would like to offer some brief comments on how Bolsonaro engages audiences (and is engaged by them). As Jan Blommaert argues in this special issue, the communication between politicians and their audiences no longer follows the linear circuits of the mass media models of the 1980s. For instance, I reproduce below a section of Veja's "letters from the readers" dedicated to the (positive) uptakes of the controversial article that Bolsonaro published about the salaries of low-ranking military members in 1886 (see Figure 12). This picture is a certain image of a homogenous circuit of communication between Bolsonaro and his fans, filtered by the mass media. This picture also iconizes a homogenized view of the public sphere (a domain of rational debate in societies, mediated by actors like the corporate media and the democratic institutions, see e.g. HABERMAS, 1989). Even though the excerpts are presented with no additional comments by the magazine, it is self-evident that these letters had gone through an editorial mediation by an acknowledged node in the public sphere: Veja received (supposedly many) letters, selected some of them, and published specific parts of the comments. Blommaert puts it that in the current online-offline nexus that characterizes contemporary societies, this image of a homogenous public sphere mediated by the corporate media and other institutions does not hold anymore - in fact, it never did, and "most serious sociologists (from Simmel and Dewey to Habermas, Bourdieu and Giddens) would frequently warn against the fallacies of such amorphous and homogenizing views of 'the public' and 'the public sphere" (Blommaert, this issue). 


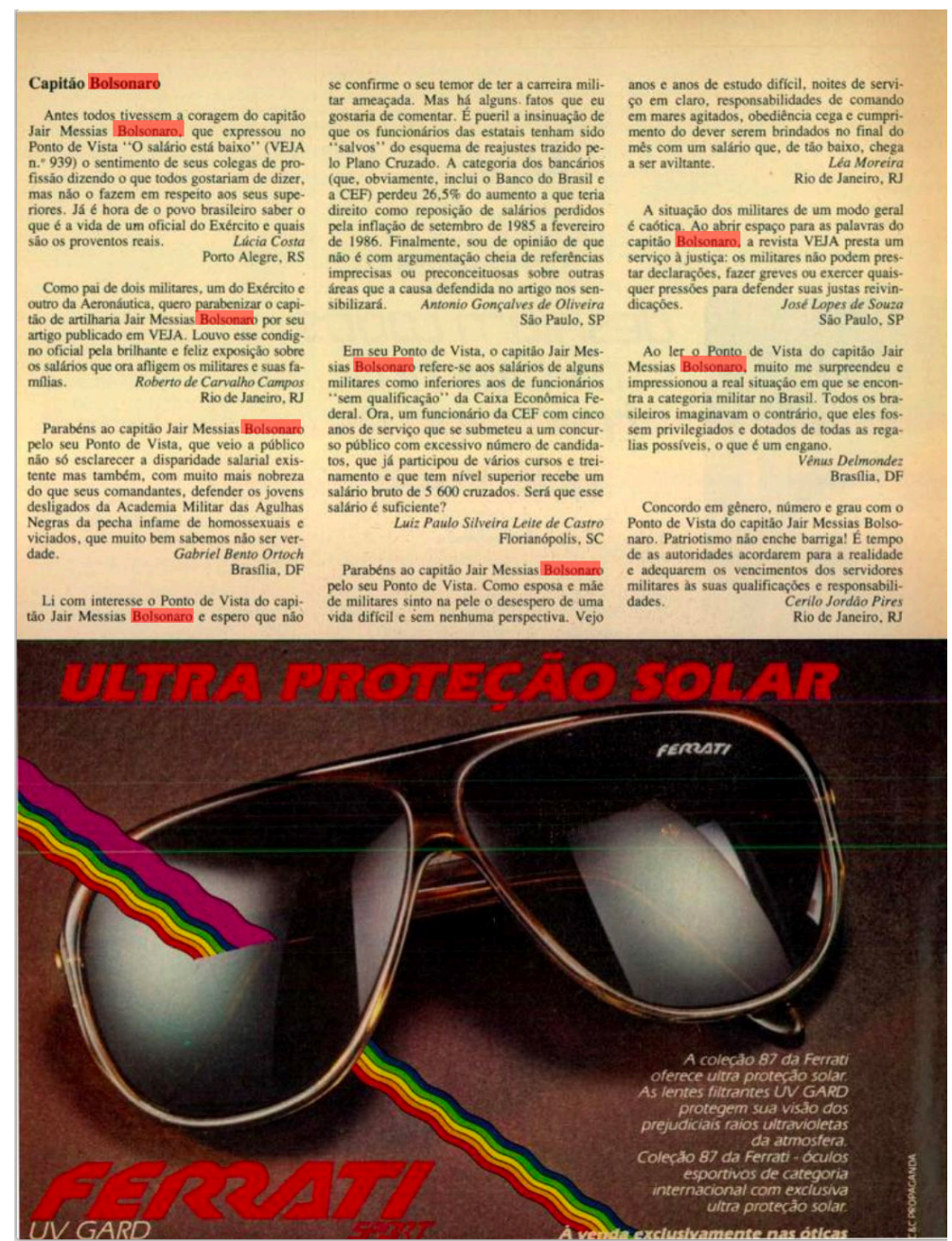

Figure 12. Letters from Veja's readers in support of Bolsonaro, Sept. 10, 1986 Copyright: Veja, Editora Abril.

Differently from this linear circuit, Blommaert points that the circulation of political messages nowadays is much more fragmented, sectorized, and algorithmicoriented (see also MALY, this issue; VARIS, this issue). Empirically, Cesarino has found evidence that in the contemporary digital networks, leaders invest in the illusion of non-mediation in social media. For instance, Bolsonaro's minister of education, Abraham Weintraub, has used Twitter to circumvent the official channels of communication in the ministry. During the massive complaints about the 2019 
national high school exam (known as ENEM) - whose grades allow students to compete for seats in public universities -, he picked some complaints by parents about their children's results on his Twitter accounts and personally directed them to being resolved by the ministry staff. One of the most visible cases was that of a father, with a pro-Bolsonaro profile on Twitter, who received the following answer by the minister about his complaint of his daughter's grade: "It is already being analyzed. Hugs." Weintraub also posted, under the comment, a print screen of a WhatsApp conversation with "Alê" (probably a staff member of the ministry) requesting the grade to be verified.

Weintraub thus builds on the idea of proximity and intimacy in the relation between influencers and their followers on social media. He resorts to a linguistic register that indexes friendship ('Hugs' instead of 'Sincerely') and affection (he publicizes a WhatsApp conversation with 'Alê', a nickname). The screen capture of his WhatsApp conversation also iconizes transparency and honesty. This performance thus projects the impression of politics being decoupled from its conventional (formal) register, old bureaucratic channels, and possibly its corrupt mechanisms, and being reassembled in intimate, "unmediated", transparent channels. Obviously, Weintraub is mediatizing, and profiting on, these affordances of social media - which are far from unmediated, with encrypted algorithms. While celebrities and influencers have long been sharp in exploiting these novel possibilities of reaching audiences, team Bolsonaro has been the first government in Brazil designed along these lines.

Moreover, as Cesarino (2019) has demonstrated in cybernetics and Blommaert (2018) in poetics, digital populists also teach their followers to speak and act like them. Blommaert (2018, p. 1-2) says: "some of [Trump's] tweets appear as chunks of discourse that can be spoken by others. In fact, they contain lots of pointers as to exactly bow they can be delivered in spoken speech. In other words, they are instructional, showing his followers how to speak like Trump". For Cesarino (2019), the discursive patterns of (team) Bolsonaro's digital populism became "fractalized across the digital landscape: anyone, anywhere with an internet connection is able to quickly and effectively pick up these discursive patterns and reproduce them intuitively. There is no need for explicit manuals, because apprehension of such patterns takes place at the subconscious level of deutero-learning". She adds that this discourse-ready-to-be-entextualized "become[s] part of users' very cognitive framing and political subjectivities - how they literally come to see the world, and act upon it." An example of this uptake by audiences and their deploying of the metapragmatic "instruction toolkit" is a video of a truck driver that circulated in 
the pro-Bolsonaro WhastApp groups. Below is a transcription of the video's initial 40 seconds:

Hi guys, good afternoon,

I will try to do a video here. I will see if I can do this video

I hope that the truck drivers share it

And I also hope that it gets to our president Bolsonaro

Who... up to the director of the Federal Road Police

Or even to the Minister of Transports

I came here to express a complaint

About the road police officers from the post in Três Marias, Minas Gerais

(...)

The truck driver embeds his message in the same metapragmatic framing of Weintraub's response to Twitter users' complaints about the national high school exam. He sees social media, and not the traditional bureaucratic channels, as the best means to reach authorities. The imagination about scales is also relevant here: he hopes that his fellow truck drivers will keep sharing the video until it reaches a chain of authorities, up to the president himself. Digital populism thus becomes a form of inhabiting a newly scaled world and making sense of it.

To bring this paper to a close, I would like to stress that the patterns that I commented on in the preceding sections - incendiary framing, smoke screens, backtracking, and avoidance of debate - also recur and intersect with this pedagogic and performative addressing of audiences. Moreover, a permanent state of agitation, resulting from this general pragmatics of chaos, affects both right and leftwing audiences. Epistemically, for pro-Bolsonaro audiences, some of the patterns that I spelt out above - like smoke curtains and incendiary framing - stoke an atmosphere of skepticism (in science, in the traditional media, in the democratic institutions but also in epistemic certainty more broadly) that is central to contemporary reactionary populisms. Bolsonaro's fabricated popular persona also indexes him as a sincere, ordinary man from the people. For anti-Bolsonaro audiences, these patterns produce dismay and discontent; progressives seem busier in contradicting Bolsonaro than in finding broader social-democratic alliances and lines of action, for example. In his discussion of Bolsonaro's method of chaos, Marcos Nobre (2019) suggests that countering the destructiveness of Bolsonaro may require a "reorganization of the disperse social democratic forces in Brazil," from right to left, who should gather to renovate the democratic institutions, that are now deeply wounded by Bolsonaro. Perhaps learning to marshal digital and semiotic affordances in a progressive direction could be an effective form of healing. 


\section{REFERENCES}

AUSTIN, John L. (1962) How to do things with words. Oxford: Oxford University Press.

BAKHTIN, Mikhail. (1984) Rabelais and bis world. Translated by Helene Iswolsky. Bloomington: Indiana University Press.

BAUMAN, R.; BRIGGS, C. (1990) Poetics and performance as critical perspectives on language and social life. Annual Review of Anthropology, v. 19, pp. 59-88.

BAUMAN, Richard. (1984) Verbal art as performance. Long Grove: Waveland Press.

BLOMMAERT, Jan (2018) Trump's Tweetopoetics. Crtl+Alt+Dem, January 19, 2018. Available at: https://bit.ly/34DfnV7. (Accessed April 8, 2020)

BLOMMAERT, Jan. (this issue) Political discourse in post-digital societies. Trabalhos em Linguística Aplicada. v. 59, n. 1.

BOLSONARO, Jair. 1986. O salário está baixo. Veja, 3 setembro 1986, p. 154.

BOURDIEU, Pierre. (1984) Distinction: A Social Critique of the Judgement of Taste. Transl. Richard Nice. Cambridge: Harvard University Press.

BRIGGS, Charles (1988) Competence in performance: The creativity of tradition in Mexicano verbal art. Philadelphia: University of Pennsylvania Press.

BRIGGS, Charles. (2005) Communicability, racial discourse, and disease. Annual Review of Anthropology. v. 34, pp. 269-291.

BRIGGS, Charles (2011) On virtual epidemics and the mediatization of public health. Language \& Communication. v. 31, pp. 217-228.

BRUM, Eliane (2018) How a homophobic, misogynist, racist 'thing' could be Brazil's next president. The Guardian. Available at: https://www.theguardian.com/ commentisfree/2018/oct/06/homophobic-mismogynist-racist-brazil-jair-bolsonaro (Accessed April 8, 2020)

CARVALHO, Luiz. (2019) O cadete e o capitão: a vida de Jair Bolsonaro no quartel. São Paulo: Todavia. 
CESARINO, Leticia (2019) On Digital Populism in Brazil. PoLAR: Political and Legal Antbropology Review. Available at: https://polarjournal.org/2019/04/15/on-jairbolsonaros-digital-populism/ (Accessed April 8, 2020)

CESARINO, Letícia. (2020) Como vencer uma eleição sem sair de casa: a ascensão do populismo digital no Brasil. Internet \& Sociedade. v. 1, n. 1, pp. 91-120.

CESARINO, Leticia. (this issue) How social media affords populist politics: remarks on liminality based on the Brazilian case. Trabalbos em Linguística Aplicada. v. 59, n. 1.

EMBURY-DENNIS, Tom. (2019) Bolsonaro ambassador threatens to choke Macron and insults wife Brigitte amid Amazon fires row: 'He sleeps with a dragon'. Independent, September 2, 2019. Available at: https://www.independent.co.uk/ news/world/americas/amazon-fires-bolsonaro-macron-brigitte-renzo-gracie-brazilambassador-a9088356.html (Accessed April 8, 2020)

FERRARI, Hamilton (2018) Bolsonaro é alvo de críticas e elogios por voltar atrás em decisões. Correio Braziliense. Available at: https://www.correiobraziliense.com. br/app/noticia/politica/2018/11/18/interna_politica,720058/bolsonaro-e-alvo-decriticas-e-elogios-por-voltar-atras-em-decisoes.shtml (Accessed April 8, 2020)

FRANKFURT, Harry. (2005) On Bullsbit. Princeton University Press.

GOFFMANN, Erving. 1974. Frame analysis: An essay on the organization of experience. New York: Harper and Row.

GRICE, H. Paul. (1975) Logic and Conversation. In: Cole, Peter and Jerry L. Morgan. (Eds.) Syntax and Semantics, v. 3, Speech Acts. New York: Academic Press, pp. 41-58.

GUMPERZ, John. (1982). Discourse strategies. Cambridge: Cambridge University Press.

HABERMAS, Jürgen. (1989) The Structural Transformation of the Public Spbere: An Inquiry into a Category of Bourgeois Society. Cambridge: The MIT Press.

HALL, Kira; GOLDSTEIN, Donna; INGRAM, Matthew (2016) The hands of Donald Trump: entertainment, gesture, spectacle. Hau: Journal of Ethnographic Theory. v. 6, p. 2, pp. $71-100$.

JACQUEMET, Marco. (in press) 45 as a Bullshit artist: Straining for charisma. In: McIntosh, Janet and Norma Mendoza-Denton. (Eds.) Language in the Trump era: Scandals and Emergencies. Cambridge: Cambridge University Press, pp. 107-118 
KROSKRITY, Paul (2000) Regimenting languages: Language ideological perspectives. In: KROSKRITY, Paul (Ed.) Regimes of language: Ideologies, polities, and identities. Santa Fe: School of American Research Press, pp. 1-34.

LACLAU, Ernesto. (2005) On Populist Reason. London: Verso.

MALY, Ico. (this issue) Algorithmic populism and the datafication and gamification of the people by Flemish Interest in Belgium. Trabalhos em Linguística Aplicada. v. 59, n. 1.

MALY, Ico. New Right Metapolitics and the Algorithmic Activism of Schild \& Vrienden. Social Media + Society, 2019. https://doi.org/10.1177/2056305119856700. (Accessed April 8, 2020)

MALY, Ico. Populism as a mediatized communicative relation: the birth of algorithmic populism. Tilburg Papers in Culture Studies 213, 2018. https://www.tilburguniversity. edu/sites/tiu/files/download/TPCS_213_Maly_2.pdf

METRO (2018) Regina Duarte compara Bolsonaro a seu pai: 'homofóbico da boca para fora'. Metro Jornal. Available at: https://www.metrojornal.com. br/entretenimento/2018/10/26/regina-duarte-compara-bolsonaro-seu-paihomofobico-da-boca-para-fora.html (Accessed April 8, 2020)

MORATO, Edwiges; BENTES, Anna Christina. (2017) "O mundo tá chato": algumas notas sobre a dimensão sociocognitiva do politicamente correto na linguagem. Revista USP. n. 115, pp. 11-28.

MOUFFE, Chantall. (2018) For a left populism. London: Verso.

NOBRE, Marcos (2019) O caos como método. Piauí. Available at: https://piaui.folha.uol. com.br/materia/o-caos-como-metodo/ (Accessed April 8, 2020)

PARAGUASSU, Lissandra. (2019) Brazil's Bolsonaro snubs French foreign minister for haircut. Reuters, July 31, 2019. Available at: https://www.reuters.com/article/ us-france-brazil/brazils-bolsonaro-snubs-french-foreign-minister-for-haircutidUSKCN1UQ21B

PINTO, Joana. (2015) Trajectories of the black female body in Brazil: Circulations of racist and antiracist representations on a TV show. Pragmatics and Society, v. 6, pp. 197-216.

RAJAGOPALAN, K. (2000) "Sobre o porquê de tanto ódio contra a linguagem 'politicamente correta'". In: F. L. Lopes da Silva; H. M. M. Moura (orgs.). O Direito à fala - A questão do preconceito linguístico. Florianópolis: Insular, pp. 93-102. 
RD1 (2019) Bolsonaro é condenado por declarações a Preta Gil e ao "CQC". RD1. Available at: https://rd1.com.br/bolsonaro-e-condenado-por-declaracoes-a-preta-gil-e-aocqc/ (Accessed April 8, 2020)

REICHMANN, Rebecca (1995) Brazil's Denial of Race. NACLA Report on the Americas, v.28, n.6, p. 35-45,

ROSALDO, Michelle. (1982). The Things We Do with Words: Ilongot Speech Acts and Speech Act Theory in Philosophy. Language in Society. v. 11, n. 2, pp. 203-237.

SAKAMOTO, Leonardo. (2020) De PIB da banana a golden shower: 8 cortinas de fumaça do governo Bolsonaro. UOL, March 5, 2020. Available at: https://noticias.uol. com.br/colunas/ leonardo-sakamoto/2020/03/05/do-pib-pifio-a-golden-shower-7cortinas-de- fumaca-do-governo-bolsonaro.htm (Accessed April 8, 2020)

SALES JR., Ronaldo. (2006) Democracia racial: o não-dito racista. Tempo social, v.18, n.2, p. 229-258.

SIGNORINI, I. (2014) A Brazilian ex-President's Public Speech: A Threat to the Existing Order? In: GORRTZEL, T.; ALMEIDA. P. R. (Ed.). The Drama of Brazilian Politics. From Dom João to Marina Silva. New York: kindle Book, p.176-194.

SILVA, Daniel (2019a) Enregistering the nation: Bolsonaro's populist branding of Brazil. In: I. Theodoropoulou, I. \& J. Woydack (Eds) Language and Country Branding. London: Routledge. Available at: https://www.academia.edu/39723047/WP252_Silva_2019. Enregistering_the_nation_Bolsonaros_populist_branding_of_Brazil (Accessed April 8, 2020)

SILVA, Daniel. (2019b) The Amazon fires as talking to Bolsonaro. Diggit Magazine. Available at: https://www.diggitmagazine.com/articles/amazon-fires-talking-bolsonaro

SILVERSTEIN, M. Language structure and linguistic ideology. In: CLYNE, P.; HANKS, W.; HOFBAUER, C. (Org.). The elements: a parasession on linguistic units and levels. Chicago: Chicago Linguistic Society, 1979. p.193-247.

THE GUARDIAN (2018) Who is Jair Bolsonaro? Brazil's far-right presidente in his own words. The Guardian, October, 29, 2018. Available at: https://www.theguardian.com/ world/2018/sep/06/jair-bolsonaro-brazil-tropical-trump-who-hankers-for-days-ofdictatorship (Accessed April 8, 2020) 
TRAUMANN, Thomas (2019) Bolsonaro usa a ambiguidade como método. Poder 360. Available at: https://www.poder360.com.br/opiniao/governo/bolsonaro-usa-aambiguidade-como-metodo-diz-traumann/ (Accessed April 8, 2020)

VARIS, Piia. (this issue) Trump tweets the truth: metric populism and media conspiracy. Trabalhos em Linguística Aplicada. v. 59, n. 1.

WOOLARD, Kathryn. (1998) Introduction: Language ideology as a field of inquiry. In: Bambi Schieffelin, Kathryn Woolard, and Paul Kroskrity (Eds.) Language ideologies: Practice and theory. New York and Oxford: Oxford University Press, pp. 3-47.

Recebido: 9/04/2020

Aceito: $13 / 04 / 2020$

Publicado: $15 / 04 / 2020$ 